Amelie Baumann

Becoming Donor-Conceived

body cultures 
This book is dedicated to my grandmother, Leni Hitz, for her unwavering support and encouragement.

Amelie Baumann is a postdoctoral researcher at Freie Universität Berlin, where she is an associated member of the Collaborative Research Centre "Affective Societies". She completed her doctorate in cultural anthropology at the University of Bremen in 2020 and was part of the interdisciplinary research project "Reconfiguring Anonymity", funded by the Volkswagen Foundation. Her research focuses on medical anthropology, the anthropology of ageing and kinship studies. 
Amelie Baumann

\section{Becoming Donor-Conceived}

The Transformation of Anonymity in Gamete Donation

[transcript] 
This publication was submitted to the doctoral committee Dr. phil. of the University of Bremen as a dissertation.

Examiners: Prof. Dr. Michi Knecht, Prof. Dr. Jeanette Edwards

The dissertation defence took place on October 23, 2020.

Funded by the Volkswagen Foundation.

An electronic version of this book is freely available, thanks to the support of libraries working with Knowledge Unlatched. $\mathrm{KU}$ is a collaborative initiative designed to make high quality books Open Access for the public good. The Open Access ISBN for this book is 978-3-8394-5731-3. More information about the initiative and links to the Open Access version can be found at www.knowledgeunlatched.org.

\section{Bibliographic information published by the Deutsche Nationalbibliothek}

The Deutsche Nationalbibliothek lists this publication in the Deutsche Nationalbibliografie; detailed bibliographic data are available in the Internet at http:// dnb.d-nb.de

\section{(c) $(1)(9)$}

This work is licensed under the Creative Commons Attribution-NonCommercialNoDerivatives 4.0 (BY-NC-ND) which means that the text may be used for non-commercial purposes, provided credit is given to the author. For details go to http://creativecommons. org/licenses/by-nc-nd/4.0/

To create an adaptation, translation, or derivative of the original work and for commercial use, further permission is required and can be obtained by contacting rights@transcriptpublishing.com

Creative Commons license terms for re-use do not apply to any content (such as graphs, figures, photos, excerpts, etc.) not original to the Open Access publication and further permission may be required from the rights holder. The obligation to research and clear permission lies solely with the party re-using the material.

\section{First published in 2021 by transcript Verlag, Bielefeld () Amelie Baumann}

Cover layout: Maria Arndt, Bielefeld

Printed by Majuskel Medienproduktion $\mathrm{GmbH}$, Wetzlar

Print-ISBN 978-3-8376-5731-9

PDF-ISBN 978-3-8394-5731-3

https://doi.org/10.14361/9783839457313

ISSN of series: $2702-9891$

eISSN of series: 2702-9905

Printed on permanent acid-free text paper. 